\title{
Potensi PP KLHS Dalam Mengintegrasikan \\ Pembangunan Berkelanjutan Dalam Penyusunan Kebijakan, Rencana, dan/atau Program
}

\author{
R. Kemala Nababan ${ }^{1}$
}

\begin{abstract}
Abstrak
Tulisan ini akan membahas potensi PP No. 46 Tahun 2016 tentang Tata Cara Penyelenggaraan Kajian Lingkungan Hidup Strategis (KLHS) dalam mengintegrasikan prinsip pembangunan berkelanjutan dalam penyusunan kebijakan, rencana, dan/atau program. Fokus kajian terbagi menjadi 3 aspek, yakni identifikasi elemen-elemen dalam prinsip pembangunan berkelanjutan yang terkandung dalam PP No. 46 Tahun 2016, proses pelaksanaan kajian lingkungan hidup strategis dan kritik terhadap proses tersebut, serta identifikasi keterlibatan masyarakat dalam penyelenggaraan KLHS. Tulisan ini juga berisi beberapa masukan terhadap peraturan pelaksanaan yang diamanatkan oleh PP No. 46 Tahun 2016 kepada peraturan menteri sehingga diharapkan pelaksanaan KLHS dapat berjalan secara lebih partisipatif, transparan, dan akuntabel.
\end{abstract}

Kata kunci: KLHS, pembangunan berkelanjutan, partisipasi publik

\section{Abstract}

This article will discuss about the potential of Government Regulation Number 46 of 2016 on Procedures for the Implementation of the Strategic Environmental Assessment (SEA) in integrating the principle of sustainable development in the formulation of policies, plans, and/or programs. The focus of the study is divided into three aspects: the identification of elements in the principles of sustainable development contained in the

1 Penulis adalah Asisten Peneliti di Indonesian Center for Environmental Law 
regulation, the mechanism of implementation of SEA and critics toward the process, as well as the identification of community involvement in the implementation of the SEA. This article also contains some input for the regulations mandated by the PP 46 of 2016 to ensure that the SEA is arranged in a more participatory, transparent, and accountable way.

Keyword: SEA, sustainable development, public participation

\section{Latar Belakang}

Degradasi kualitas lingkungan hidup yang lajunya kian meningkat memaksa pengambil keputusan untuk menetapkan langkah-langkah perlindungan lingkungan yang lebih progresif. Kajian Lingkungan Hidup Strategis (selanjutnya disebut sebagai KLHS) kemudian muncul untuk menjawab permasalahan dan tantangan tersebut, yang pengaturannya muncul dalam rezim berlakunya UU No. 32 Tahun 2009 tentang Perlindungan dan Pengelolaan Lingkungan Hidup (UU PPLH). Undang-undang tersebut mewajibkan Pemerintah dan Pemerintah Daerah untuk membuat KLHS guna memastikan prinsip pembangunan berkelanjutan telah menjadi dasar dan terintegrasi dalam pembangunan suatu wilayah dan/atau kebijakan, rencana, dan/atau program (selanjutnya disingkat KRP). ${ }^{2}$ Pengaturan mengenai KLHS di dalamnya belum komprehensif dan masih bersifat umum. Untukitu, undang-undang ini memerintahkan agar dibentuk peraturan pemerintah yang mengatur lebih rinci mengenai tata cara penyelenggaraan KLHS. ${ }^{3}$

Peraturan pemerintah sebagaimana dimaksud dalam Pasal 18 ayat (2) UU PPLH baru muncul beberapa tahun setelahnya, yakni pada tahun 2016 melalui PP No. 46 Tahun 2016 tentang Tata Cara Penyelenggaraan Kajian Lingkungan Hidup Strategis (KLHS). Karena peraturan pemerintah ini baru muncul relatif lama sejak diperintahkan oleh undang-undangnya, maka beberapa peraturan menteri yang mengatur hal sejenis sudah muncul terlebih dahulu. Peraturan tersebut di antaranya Peraturan Menteri Lingkungan Hidup No. 9 Tahun 2011 tentang Pedoman Umum KLHS serta Peraturan Menteri Dalam Negeri No. 27 Tahun 2012 tentang Pedoman Pelaksanaan KLHS dalam Penyusunan atau Evaluasi Rencana Pembangunan Daerah.

\footnotetext{
2 Indonesia, Undang-Undang Perlindungan dan Pengelolaan Lingkungan Hidup, UU No. 32 Tahun 2009, LN No. 140 Tahun 2009, TLN No. 5059, Ps. 15 ayat (1).

3 Ibid., Ps. 18 ayat (2).
} 
Beberapa pokok yang perlu diperhatikan dalam PP No. 46 Tahun 2016 adalah mengenai prinsip pembangunan berkelanjutan yang dikandung di dalamnya, jaminan atas keterlibatan masyarakat, dan mekanisme pelaksanaan KLHS. Ketiga hal tersebut perlu untuk diperhatikan dan akan diulas dalam tulisan ini, karena akan menentukan kualitas dari sebuah KLHS. Di samping itu, ketiga hal tersebut pula yang secara langsung berkaitan dengan proses tujuan dibuatnya suatu KLHS, yaitu untuk memastikan bahwa prinsip pembangunan berkelanjutan telah menjadi dasar dan terintegrasi ke dalam pembangunan suatu wilayah dan/atau KRP, sebagaimana diamanatkan dalam Pasal 1.

\section{Prinsip Pembangunan Berkelanjutan dalam PP No. 46 Tahun 2016}

Pembangunan berkelanjutan didefinisikan sebagai pembangunan yang memenuhi kebutuhan masa kini tanpa mengurangi kemampuan generasi mendatang untuk mencukupi kebutuhan mereka sendiri. ${ }^{4}$ Prinsip pembangunan berkelanjutan menjadi salah satu isu yang dianalisis dalam tulisan ini, mengingat bahwa prinsip tersebutlah yang pada intinya hendak diintegrasikan ke dalam suatu KRP. Untuk itu, perlu pula ditelaah lebih jauh apakah PP No. 46 Tahun 2016 sudah mengakomodir elemen-elemen dalam prinsip pembangunan berkelanjutan.

Menurut Chay Asdak, secara substansial, KLHS merupakan suatu upaya sistematis dan logis dalam memberikan landasan bagi terwujudnya pembangunan berkelanjutan melalui proses pengambilan keputusan yang lebih berwawasan lingkungan. ${ }^{5}$ Lebih lanjut lagi, Asdak mengemukakan bahwa KLHS merupakan "alat" untuk mengintegrasikan kepentingan-kepentingan lingkungan hidup dan/atau prinsip pembangunan berkelanjutan ke dalam proses pengambilan keputusan. ${ }^{6}$ Dari definisi pembangunan berkelanjutan yang dikemukakan oleh World Commission on Environment and Development (WCED), dapat diturunkan beberapa elemen-elemen inti dari pembangunan berkelanjutan. Elemen-elemen tersebut yakni elemen integrasi, pemanfaatan secara berkelanjutan, keadilan intra

$4 \quad$ Komisi Dunia untuk Lingkungan dan Pembangunan (World Commission on Environment and Development), Hari Depan Kita Bersama, (Jakarta: PT Gramedia, 1988) hlm. 59.

5 Chay Asdak, Kajian Lingkungan Hidup Strategis: Jalan Menuju Pembangunan Berkelanjutan, (Yogyakarta: Gadjah Mada University Press, 2012), hlm. 46.

$6 \quad$ Ibid., hlm. 48. 
generasi, dan keadilan antargenerasi. PP No. 46 Tahun 2016 tidak mencantumkan secara eksplisit mengenai elemen-elemen tersebut dalam suatu pasal, namun keberadaanya dapat ditelaah dalam batang tubuh peraturan tersebut. Secara umum, PP No. 46 Tahun 2016 telah mengandung beberapa elemen dalam konsep pembangunan berkelanjutan, yakni:

1. Prinsip integrasi

Prinsip ini merupakan komitmen untuk mengintegrasikan pertimbangan lingkungan ke dalam pembangunan, dan untuk memperhatikan kebutuhan akan pembangunan ekonomi dan sosial dalam penyusunan kewajiban lingkungan. ${ }^{7}$ Hal ini secara tegas dirumuskan dalam Pasal 2 ayat (1) PP No. 46 Tahun 2016, yang menyatakan bahwa Pemerintah Pusat dan Pemerintah Daerah wajib membuat KLHS untuk memastikan bahwa prinsip pembangunan berkelanjutan telah menjadi dasar dan terintegrasi dalam pembangunan suatu wilayah dan/atau Kebijakan, Rencana, dan/atau Program. Peraturan ini juga telah merumuskan mengenai kriteria KRP yang wajib untuk dibuat KLHS-nya.

2. Prinsip pemanfaatan berkelanjutan

Dalam perspektif hukum, pemanfaatan berkelanjutan (sustainable use) dimaknai sebagai pemanfaatan sumber daya hayati dengan cara dan dalam laju pemanfaatan yang dalam jangka panjang tidak akan mengarah pada penurunan keanekaragaman hayati, sehingga mampu menjaga potensi sumber daya keanekaragaman hayati untuk memenuhi kebutuhan generasi sekarang dan yang akan datang. ${ }^{8}$ Prinsip ini diakomodir oleh Pasal 13 ayat (1) huruf d PP No. 46 Tahun 2016, di mana efisiensi pemanfaatan sumber daya alam ${ }^{9}$ menjadi salah satu pertimbangan dalam melakukan analisis materi muatan KRP pada tahap pembuatan KLHS.

$7 \quad$ Philippe Sands, Principles of International Environmental Law: Vol. 1, Frameworks, Standards and Implementation (Manchester University Press, 1995), hlm. 199.

8 United Nation Convention on Biological Diversity, Article 2.

9 Bagian Penjelasan PP No. 46 Tahun 2016 menyatakan bahwa efisiensi pemanfaatan sumber daya alam merupakan upaya memanfaatkan sumber daya alam dalam tingkat yang optimal sehingga dapat tetap melestarikan sumber daya alam serta beserta ekosistemnya. Efisiensi pemanfaatan sumber daya alam di antaranya dapat berupa pencadangan sumber daya alam untuk dikelola dalam jangka panjang dan waktu tertentu sesuai dengan kebutuhan. 


\section{Prinsip keadilan intragenerasi}

Keadilan intragenerasi merupakan keadilan yang ditujukan pada mereka yang hidup dalam satu generasi, yang berkaitan dengan distribusi sumber daya secara adil. ${ }^{10}$ Dari perspektif keadilan distributif, keadilan intragenerasi dalam PP No. 46 Tahun 2016 dinyatakan melalui adanya pertimbangan mengenai tingkat dan status jumlah penduduk miskin atau penghidupan sekelompok masyarakat serta terancamnya keberlanjutan penghidupan masyarakat. ${ }^{11}$ Pertimbangan ini menjadi perlu, mengingat kondisi ketidakadilan lingkungan bisa ditunjukkan dengan merujuk pada pembagian sumber daya alam dan pemanfaatan yang tidak merata, ataupun pada pembagian resiko kerusakan lingkungan yang juga tidak seimbang. Selama ini dapat dilihat bahwa dampak terjadinya degradasi kualitas lingkungan lebih sering dirasakan oleh penduduk lokal, masyarakat adat, atau rakyat miskin. ${ }^{12}$ Dengan mempertimbangkan masyarakat tertentu yang kedudukannya lemah, maka diharapkan ketidakmerataan pembagian manfaat dan resiko lingkungan dari suatu KRP dapat diminimalisir.

Dari perspektif keadilan prosedural, PP No. 46 Tahun 2016 juga mengakomodir terciptanya keadilan intragenerasi. Keadilan prosedural merupakan keadilan untuk memperoleh perlakuan yang sama dalam hal mendapatkan perhatian (concern and respect) dalam pengambilan keputusan politik terkait barang dan kesempatan. ${ }^{13}$ Keadilan prosedural ini dinyatakan melalui pelibatan masyarakat dan pemangku kepentingan dalam pembuatan KLHS yang diatur secara khusus dalam Bab III PP No. 46 Tahun 2016. Perihal keterlibatan masyarakat dan pemangku kepentingan akan dibahas lebih lanjut pada bagian berikutnya dalam tulisan ini.

10 Sharon Beder, Environmental Principles and Policies: An Interdiciplinary Introduction (Earthscan, 2006), hlm. 71.

11 Indonesia, Peraturan Pemerintah tentang Tata Cara Penyelenggaraan Kajian Lingkungan Hidup Strategis, PP No. 46 Tahun 2016, LN No. 228 Tahun 2016, TLN No. 5941, Ps. 9 ayat (2) huruf h.

12 Indonesian Center for Environmental Law, Materi Ajar Pendidikan dan Pelatihan Sertifikasi Hakim Lingkungan Hidup, 2012, hlm. 69

13 Kuehn, dalam Indonesian Center for Environmental Law, Materi Ajar Pendidikan dan Pelatihan Sertifikasi Hakim Lingkungan Hidup, 2012, hlm. 81. 


\section{Prinsip keadilan antargenerasi}

Keadilan antargenerasi dapat dengan jelas dipahami melalui rumusan pengertian pembangunan berkelanjutan yang dikemukakan oleh World Commission on Environmental and Development (WCED). Pengertian tersebut menekankan bahwa pembangunan yang dilakukan tidak boleh mengkompromikan kemampuan generasi berikutnya untuk memenuhi sendiri kebutuhan mereka. Keadilan antargenerasi juga menekankan bahwa generasi sekarang memiliki dua fungsi, yaitu sebagai trustees dan beneficiaries. Sebagai trustees, generasi sekarang bertanggung jawab atas kesatuan lingkungan hidup, sedangkan sebagai beneficiaries, generasi sekarang memiliki hak untuk memanfaatkannya. ${ }^{14}$

PP No. 46 Tahun 2016 dalam rumusan-rumusan pasalnya telah mengakomodir elemen keadilan antargenerasi. Pasal 3 ayat (2) huruf a peraturan tersebut menyatakan bahwa KRP yang berpotensi menimbulkan dampak dan/atau risiko lingkungan hidup berupa kerusakan, kemerosotan, dan/atau kepunahan keanekaragaman hayati adalah KRP yang wajib memiliki KLHS. Pasal tersebut juga mewajibkan KRP yang berpotensi menimbulkan dampak berupa penurunan mutu dan kelimpahan sumber daya alam agar memiliki KLHS. Kedua pertimbangan mengenai KRP yang wajib KLHS ini sejalan dengan konsep keadilan antargenerasi yang dikemukakan oleh Edith Brown Weiss. ${ }^{15}$ Menurut Weiss, konsep keadilan antargenerasi telah melahirkan kewajiban lingkungan berupa tiga jenis perlindungan: perlindungan opsi, perlindungan kualitas, dan perlindungan atas akses. Dalam kerangka ini, rumusan Pasal 3 ayat (2) huruf a sebagaimana dikemukakan di atas mencerminkan ketiga jenis perlindungan tersebut. Perlindungan opsi menginginkan agar generasi mendatang setidaknya memiliki pilihan-pilihan yang sama dengan pilihan yang tersedia bagi generasi sekarang. ${ }^{16}$ Perlindungan atas kualitas

14 Edith Brown Weiss, "In Fairness to Future Generations and Sustainable Development," American University Law International Review, 1992, hlm. 20.

15 Profesor hukum dari Georgetown University Law Center yang banyak melakukan kajian mengenai hukum dan lingkungan hidup. Weiss juga merupakan anggota dari International Advisory Council on Environmental Justice for United Nations Environment Programme's on the Rule of Law.

16 Edith Brown Weiss, "Intergenerational Equity and Rights of Future Generations," The Modern of Human Rights: Essays in Honor of Thomas Buergenthal, hal. 608. 
menginginkan agar kita meninggalkan kualitas alam dan lingkungan hidup tidak lebih buruk dari kualitas yang kita terima dari generasi sebelumnya. ${ }^{17}$ Perlindungan atas akses menginginkan agar generasi sekarang memikul kewajiban untuk menjamin bahwa tindakannya tidak akan mengurangi akses generasi yang akan datang terhadap sumber daya alam. ${ }^{18}$ Dari uraian di atas, dapat disimpulkan bahwa mewajibkan pembuatan KLHS terhadap kegiatan yang berpotensi menimbulkan kerusakan, kemerosotan, dan/atau keanekaragaman hayati dan yang berpotensi mengakibatkan penurunan mutu dan kelimpahan sumber daya alam telah mencerminkan perlindungan dan keadilan bagi generasi mendatang.

\section{Pelaksanaan Kajian Lingkungan Hidup Strategis}

Secara sederhana, alur penyelenggaraan KLHS dapat dilihat pada gambar di bawah ini.

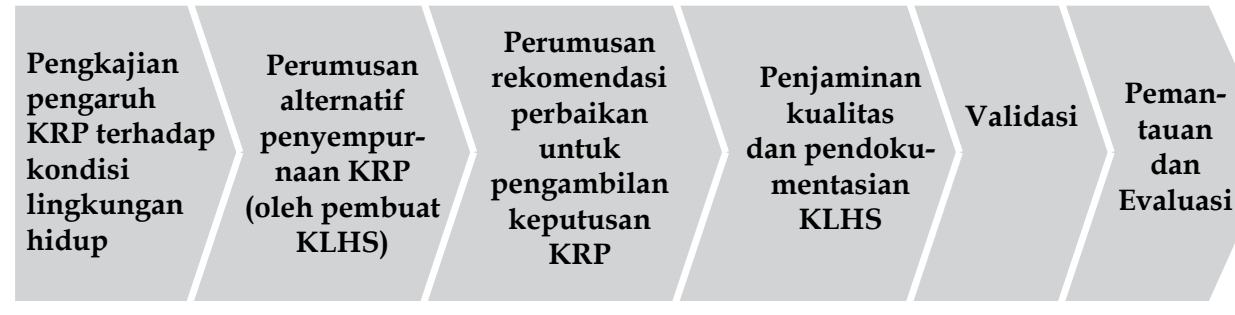

Pembuatan KLHS

Gambar 1 Alur Penyelenggaraan Kajian Lingkungan Hidup Strategis

Penyelenggaraan KLHS secara garis besar terdiri atas 3 tahap. ${ }^{19}$ Pertama, tahap pembuatan dan pelaksanaan KLHS. Ada 3 kegiatan utama yang dilakukan pada tahap ini, yaitu pengkajian pengaruh KRP terhadap kondisi lingkungan hidup yang dilakukan oleh penyusun KLHS yang memenuhi standar kompetensi; perumusan alternatif penyempurnaan KRP; dan penyusunan rekomendasi perbaikan untuk pengambilan keputusan KRP yang mengintegrasikan prinsip pembangunan berkelanjutan. Pada tahap inilah dipertimbangkan faktor-faktor

17 Ibid.

18 Ibid., hlm. 609.

19 PP No. 46 Tahun 2016, Ps. 5. 
seperti kapasitas daya dukung dan daya tampung lingkungan hidup, perkiraan dampak dan resiko lingkungan hidup, dan sebagainya. Kedua, tahap penjaminan kualitas dan pendokumentasian KLHS. Penjaminan kualitas dilakukan melalui penilaian mandiri oleh penyusun KRP untuk memastikan bahwa kualitas dan proses pembuatan dan pelaksanaan KLHS dilaksanakan sesuai dengan ketentuan yang berlaku. ${ }^{20}$ Hasil penjaminan kualitas KLHS harus disusun secara tertulis dengan memuat informasi tentang kelayakan KLHS jika telah memenuhi ketentuan dan/atau rekomendasi perbaikan KLHS yang telah diikuti dengan perbaikan KRP. ${ }^{21}$ Ketiga, tahap validasi yang diselenggarakan untuk memastikan penjaminan kualitas telah dilaksanakan secara akuntabel dan dapat dipertanggungjawabkan kepada publik. ${ }^{22}$

Mekanisme penyelenggaraan KLHS sebagaimana dijabarkan di atas turut mempengaruhi kedudukan KLHS tersebut, terutama mengenai dapat atau tidaknya KLHS mengintervensi suatu KRP. Untuk itu, salah satu hal yang menarik untuk dibahas adalah mengenai penjaminan kualitas dan validasi KLHS. Penjaminan kualitas yang dilakukan melalui penilaian mandiri oleh penyusun KRP dikhawatirkan tidak akan membawa perubahan atas KRP yang ternyata, misalnya, melampaui daya dukung dan daya tampung lingkungan hidup. Untuk menghindari hal ini maka seharusnya ada pihak lain di luar penyusun KRP agar upaya penilaian mandiri dapat berlangsung secara partisipatif dan akuntabel.

Kekhawatiran mengenai tidak akuntabelnya penjaminan kualitas sebenarnya dapat diatasi dengan adanya tahap validasi yang diatur dalam Pasal 25 sampai Pasal 31 PP No. 46 Tahun 2016. Setelah penjaminan kualitas diselenggarakan, maka terhadap rumusan KLHS dilakukan validasi oleh Menteri (untuk KRP tingkat nasional dan provinsi) atau gubernur (untuk KRP tingkat kabupaten/kota). ${ }^{23}$ Permohonan validasi diajukan oleh pembuat KRP dengan melampirkan dokumen berupa rancangan KRP, laporan KLHS, dan bukti pemenuhan standar kompetensi penyusun KLHS. ${ }^{24}$ Menteri atau gubernur kemudian melakukan pemeriksaan

\footnotetext{
20 Ibid., Ps. 19 ayat (1).

21 Ibid., Ps. 20 ayat (1).

22 Ibid., Ps. 25 ayat (2).

23 Ibid., Ps. 25 ayat (1).

24 Ibid., Ps. 26 ayat (1).
} 
kelengkapan permohonan tersebut. Apabila permohonan lengkap, maka menteri atau gubernur akan menerbitkan persetujuan validasi dalam waktu paling lama 20 hari kerja sejak kepada penyusun KRP. ${ }^{25}$ Persetujuan validasi atas KLHS yang telah memenuhi syarat paling sedikit memuat kesesuaian hasil KLHS dengan penjaminan kualitas, dan di samping itu juga harus memuat rekomendasi. Jika hasil pemeriksaan menunjukkan bahwa permohonan tidak lengkap, menteri atau gubernur akan mengembalikan dokumen tersebut kepada penyusun KRP untuk dilengkapi. ${ }^{26}$ Namun, dalam PP No. 46 Tahun 2016 pengaturan mengenai validasi ini masih belum jelas, apakah menteri atau gubernur hanya berfungsi untuk melakukan pemeriksaan secara administratif ataukah dapat juga melakukan pemeriksaan secara substantif. Hal ini dapat menjadi bahan pertimbangan dalam membuat peraturan menteri yang diamanatkan dalam Pasal 31 PP No. 46 Tahun 2016. Diharapkan dalam peraturan pelaksanaan tersebut, menteri atau gubernur dapat melakukan pemeriksaan secara substantif.

Apabila menteri atau gubernur dapat melakukan pemeriksaan tidak hanya terhadap kelengkapan dokumen namun juga pemeriksaan terhadap substansi KLHS, maka akuntabilitas penjaminan kualitas KLHS melalui penilaian mandiri dapat dipertanggungjawabkan, meskipun pada dasarnya tetap tidak efektif. Persoalan ini yang juga sebaiknya diatur dalam peraturan menteri mengenai validasi KLHS. Dalam peraturan menteri tersebut selanjutnya perlu diatur mengenai bentuk dari persetujuan validasi KLHS, misalnya persetujuan validasi ditetapkan melalui surat keputusan. Di samping itu, yang tak kalah penting untuk diatur adalah mengenai konsekuensi dari tidak adanya persetujuan validasi terhadap KLHS serta konsekuensi hukum apabila penyusun KRP tidak melaksanakan rekomendasi dari Menteri atau gubernur.

Sebagai bahan pertimbangan atas permasalahan yang dikemukakan di atas, Indonesia dapat merujuk pada model penyelenggaraan KLHS di Kanada. Sejak tahun 1990 Kanada telah menerbitkan peraturan mengenai Environmental Assessment Process for Policy and Program Proposals yang mensyaratkan perlunya kajian lingkungan hidup atas semua KRP yang diusulkan oleh pemerintah. Mekanisme pembuatan KLHS di Kanada secara umum hampir sama dengan

25 Ibid., Ps. 26 ayat (3).

26 Ibid., Ps. 26 ayat (5). 
mekanisme pembuatan KLHS di Indonesia. Bedanya, penjaminan kualitas (quality assurance) dalam penyelenggaraan KLHS Kanada menjadi kewajiban Menteri Lingkungan Hidup, sebagaimana dikutip sebagai berikut. ${ }^{27}$

The Minister of the Environment with the approval of the Governor-in-Council should strengthen the quality of SEA development by Directing Canadian Environmental Assessment Agency (CEAA) to provide more support to departments in ensuring quality by providing and sharing best practices, e.g., through case studies and quality review procedures.

Kutipan di atas menunjukkan bahwa peran Menteri Lingkungan Hidup Kanada adalah mengarahkan CEAA $^{28}$ untuk memberikan dukungan misalnya melalui quality review kepada pembuat KRP. Di samping itu, Menteri Lingkungan Hidup Kanada juga mengarahkan agar pembuat KRP untuk menerapkan langkahlangkah yang lebih besar untuk menjamin bahwa perumusan Strategic Environmental Assessment (SEA) telah benar-benar mempertimbangkan faktor-faktor lingkungan dan melibatkan masyarakat. ${ }^{29}$ Meskipun penjaminan kualitas SEA di Kanada dilakukan melalui penilaian mandiri, tetap ada campur tangan dari lembaga lain, yakni Menteri Lingkungan Hidup dan Canadian Environmental Assessment Agency. Oleh sebab itu, tidak diperlukan adanya tahapan validasi dalam penyelenggaraan KLHS di Kanada.

Dari perbandingan mengenai penjaminan kualitas dan validasi KLHS antara Indonesia dan Kanada di atas, dapat disimpulkan bahwa model yang diadopsi oleh Kanada lebih efektif dibandingkan Indonesia. Di Indonesia, karena penjaminan kualitas dilakukan secara mandiri, maka untuk menjamin akuntabilitasnya dibutuhkan satu tahapan lagi, yakni validasi yang sebagaimana disebutkan sebelumnya, belum tentu menyentuh masalah substansi KLHS. Tahapan validasi ini tidak terlihat pada proses penyelenggaraan KLHS di Kanada, karena

27 Stratos, Evaluation of The Cabinet Directive on The Environmental Assessment of Policy, Plan and Program Proposals, (Ottawa: Stratos Inc, 2009), hlm. 48.

28 Canadian Environmental Assessment Agency adalah lembaga pemerintahan di bawah The Federal Minister of The Environment di Kanada. Lembaga ini bertanggung jawab untuk melaksanakan proses penilaian lingkungan, terutama untuk memperkuat partisipasi publik, meningkatkan kualitas penilaian melalui pelatihan dan pembinaan, dan mengarusutamakan penggunaan kajian lingkungan hidup strategis sebagai kunci untuk perumusan kebijakan yang mempertimbangkan keberlanjutan.

29 Stratos, Op. Cit., hlm. 47. 
penjaminan kualitasnya sendiri sudah cukup untuk memastikan bahwa faktorfaktor lingkungan sudah menjadi pertimbangan dalam penyusunan KRP.

Sebagai organisasi yang bergerak dalam pengembangan hukum lingkungan di Indonesia, Indonesian Center for Environmental Law (ICEL) memandang bahwa penjaminan kualitas tidak cukup dilakukan melalui penilaian mandiri oleh penyusun KRP saja. Dalam penyusunan PP KLHS ini, ICEL mengusulkan agar pembuat KRP menunjuk tim penilai yang bertujuan untuk melakukan penilaian mandiri terhadap proses pembuatan KLHS. Tim penilaian mandiri dibentuk dan bertugas bersamaan dengan dimulainya tahap pengkajian pengaruh KRP sampai dengan tahap pendokumentasian KLHS. ICEL juga mengusulkan agar tim penilai ini terdiri atas ahli dari instansi teknis yang membidangi KRP yang bersangkutan, instansi lingkungan hidup, ahli lain dari bidang ilmu yang terkait, masyarakat, organisasi lingkungan hidup, dan unsur lainnya. ${ }^{30}$

Secara prosedural, PP No. 46 Tahun 2016 dapat mengintervensi KRP yang melebihi daya dukung dan daya tampung lingkungan hidup. Hal ini terutama dapat dilihat dalam tahap pembuatan dan pelaksanaan KLHS. Pada bagian penyusunan rekomendasi perbaikan untuk pengambilan KRP (yang dilakukan setelah pengakajian pengaruh KRP terhadap lingkungan hidup), disebutkan bahwa rekomendasi tersebut salah satunya memuat informasi jenis usaha dan/atau kegiatan yang telah melampaui daya dukung dan daya tampung lingkungan hidup dan tidak diperbolehkan lagi. ${ }^{31}$ Namun, sebagaimana dikemukakan sebelumnya, intervensi KLHS terhadap KRP akan sulit dilakukan mengingat penjaminan kualitasnya dilakukan melalui penilaian mandiri, tanpa adanya tim penilai.

\section{Keterlibatan Masyarakat dalam Penyelenggaraan Kajian Lingkungan Hidup Strategis}

Partisipasi masyarakat merupakan salah satu aspek yang penting untuk diperhatikan dalam penyelenggaraan KLHS. Sebagai sebuah proses yang sistematis, rangkaian proses penyelenggaraan KLHS sudah seharusnya dilakukan

30 Indonesian Center for Environmental Law, “Tabel Perbandingan Rancangan Peraturan Pemerintah tentang KLHS," 2014.

31 PP No. 46 Tahun 2016, Ps. 16 huruf (b). 
dengan pendekatan konsultatif-partisipatif. Dengan pendekatan tersebut diharapkan kualitas pengambilan keputusan dapat meningkat, di mana unsurunsur pembangunan berkelanjutan yang menyangkut banyak pihak sudah dipertimbangkan sejak dini dalam proses awal perencanaan. ${ }^{32}$

Kewajiban melibatkan masyarakat dan pemangku kepentingan dalam PP No. 46 Tahun 2016 terdapat pada tahap pembentukan dan pelaksanaan KLHS, terutama pada saat melakukan identifikasi dan perumusan isu pembangunan berkelanjutan. ${ }^{33}$ Keterlibatan ini meliputi pemberian pendapat, saran, dan usul, pendampingan tenaga ahli, bantuan teknis, serta penyampaian informasi dan/atau laporan. Meskipun demikian, rumusan pasal dalam PP No. 46 Tahun 2016 ternyata tidak mengakomodir keterlibatan masyarakat untuk tahap-tahap selanjutnya, yakni penjaminan kualitas dan validasi KLHS.

Merujuk pada tangga partisipasi yang dikemukakan oleh Arnstein, ${ }^{34}$ maka dapat dipahami bahwa partisipasi masyarakat dalam penyelenggaraan KLHS berdasarkan PP No. 46 Tahun 2016 berada pada anak tangga keempat, yakni consultation. Pada tingkatan ini, masyarakat diberikan kesempatan untuk didengarkan pendapat, saran, dan usulannya dalam berbagai konsultasi publik namun tidak terlibat secara langsung dalam pengambilan keputusan. ${ }^{35}$

Pelibatan masyarakat dalam penyelenggaraan KLHS sejatinya tidak cukup hanya sampai pada level consultation. Hak memberi pendapat, penyampaian keberatan, dan pengawasan perlu juga dilekatkan kepada masyarakat, agar bentuk partisipasi tersebut meningkat ke level keenam, yaitu partnership menurut konsep Arnstein. Jaminan terhadap partisipasi masyarakat hingga ke level partnership menjadi penting terutama karena masyarakatlah yang merasakan dampak dari suatu KRP, sehingga sudah sepatutnya pendapat masyarakat memiliki pengaruh dalam pengambilan keputusan.

\section{Chay Asdak,Op. Cit., hlm. 116.}

33 PP No. 46 Tahun 2016, Ps. 8 ayat (2).

34 Tangga partisipasi menurut konsep Arnstein terdiri dari: (1) manipulation; (2) therapy; (3) informing; (4) consultation; (5)placation; (6) partnership; (7) delegated power; dan (8) citizen power (Lihat: Arnstein, A Ladder of Participation, JAIP, Vol. 35,No. 4, July 1969, hlm. 216-224).

35 Sherry R. Arnstein, “A Ladder of Citizen Participation," dalam JAIP, Vol. 35, No. 4, July 1969 , hlm. 221. 
Dalam penyelenggaraan KLHS dibutuhkan pelibatan masyarakat yang sifatnya lebih deliberatif. Hal ini erat kaitannya dengan keadilan prosedural seperti sudah disinggung pada poin sebelumnya. Dalam proses deliberatif ini pihak yang lemah (baik secara ekonomi, politik, maupun sosial) diberikan bantuan sumber daya, teknis, dan hukum yang akan memungkinkan mereka untuk memperoleh akses yang lebih besar dalam pengambilan keputusan. ${ }^{36}$ Proses yang deliberatif ini dapat diwujudkan melibatkan masyarakat tidak hanya sampai tahap identifikasi dan perumusan isu pembangunan berkelanjutan, tapi juga dalam hal pengawasan, keberatan, pengambilan keputusan, serta pemantauan dan evaluasi. Mekanisme keberatan, terutama diperlukan dalam hal masyarakat tidak diberikan kesempatan untuk terlibat, atau apabila ternyata dalam praktiknya proses dan isi KLHS tertutup.

Permasalahan yang mendasar dalam kaitannya dengan partisipasi masyarakat dalam PP No. 46 Tahun 2016 adalah mengenai notifikasi adanya KRP dan KLHS. Dalam peraturan tersebut, tidak ada kewajiban bagi penyusun KRP untuk melakukan notifikasi untuk memberitahukan adanya rencana KRP. Notifikasi diperlukan agar masyarakat mengenal sedini mungkin rencana KRP agar tersedia cukup waktu bagi masyarakat untuk menelaah rencana KRP, termasuk dokumen KLHS yang telah disusun.

\section{Penutup}

Pengaturan mengenai kajian lingkungan hidup strategis dalam PP No. 46 Tahun 2016 pada dasarnya sudah komprehensif, namun masih memiliki celah yang berpotensi menyebabkan tidak efektifnya pengintegrasian prinsip pembangunan berkelanjutan dalam sebuah KRP. Celah tersebut yakni terkait penjaminan kualitas dan validasi serta mekanisme pelibatan masyarakat yang menurut konsep Arnstein belum mencapai tahap partnership. .

Untuk mencapai tujuan sejatinya, perlu komitmen dari para pemangku kepentingan untuk menyelenggarakan KLHS secara lebih partisipatif, transparan, dan akuntabel. Di samping itu, ada beberapa hal yang pelu dipertimbangkan apabila pemerintah hendak merumuskan peraturan pelaksanaan dari PP No.

36 Kuehn, dalam Materi Ajar Sertifikasi Hakim Lingkungan, Op. Cit., hlm. 81 
46 Tahun 2016, terutama mengenai kewenangan menteri atau gubernur dalam melakukan pemeriksaan terhadap substansi kesesuaian hasil KLHS dengan penjaminan kualitas yang telah dilakukan secara mandiri oleh penyusun KLHS. 


\section{DAFTAR PUSTAKA}

Arnstein, Sherry R. 1969. “A Ladder of Citizen Participation," dalam JAIP, Volume 35, No. 4.

Asdak, Chay. 2012. Kajian Lingkungan Hidup Strategis: Jalan Menuju Pembangunan Berkelanjutan. Yogyakarta: Gadjah Mada University Press.

Indonesia. Peraturan Pemerintah tentang Tata Cara Penyelenggaraan Kajian Lingkungan Hidup Strategis. PP No. 46 Tahun 2016. LN No. 228 Tahun 2016. TLN No. 5941.

Indonesia. Undang-Undang Perlindungan dan Pengelolaan Lingkungan Hidup. UU No. 32 Tahun 2009. LN No. 140 Tahun 2009. TLN No. 5059.

Indonesian Center for Environmental Law, “Tabel Perbandingan Rancangan Peraturan Pemerintah tentang KLHS.

Indonesian Center for Environmental Law. 2012. Materi Ajar Pendidikan dan Pelatihan Sertifikasi Hakim Lingkungan Hidup. Jakarta: ICEL dan Pusat Pendidikan dan Pelatihan Teknis Peradilan Mahkamah Agung Republik Indonesia.

Komisi Dunia untuk Lingkungan dan Pembangunan (World Commission on Environment and Development). 1988. Hari Depan Kita Bersama. Jakarta: PT Gramedia.

Sands, Philippe. 1995. Principles of International Environmental Law: Vol. 1, Frameworks, Standards and Implementation. Manchester: Manchester University Press.

Sharon Beder, Environmental Principles and Policies: An Interdiciplinary Introduction (Earthscan, 2006)

Stratos. 2009. Evaluation of The Cabinet Directive on The Environmental Assessment of Policy, Plan and Program Proposals. Ottawa: Stratos Inc.

United Nation Convention on Biological Diversity. 1992.

Weiss, Edith Brown. 1992. "Intergenerational Equity and Rights of Future Generations," dalam The Modern of Human Rights: Essays in Honor of Thomas Buergenthal.

Weiss, Edith Brown. 1989. "In Fairness to Future Generations and Sustainable Development," dalam American University Law International Review Vol. 8 Issue 1. 
